\title{
NEW NEUROPTEROID INSECTS FROM THE UNITED STATES
}

\section{By Nathan Banks}

The following notes include a synoptic table to the species of Boriomyia and the description of three new genera of Trichoptera. The new Psocidæ represents a genus new to our fauna, quite different from anything else in the country.

\section{PSOCID $\#$}

\section{Deipnopsocus texanus sp. nov.}

Figs. 1, 2.

Body yellowish to reddish brown, no distinct markings, head with sparse, short white hair, longer on the clypeus; legs pale yellowish brown, with some white hair, few bristles, front femora broad and compressed. Wings hyaline, surface with a few scattered, short, minute, rounded scales, several rows of them on margin all around wing, some of these more elongate and pointed; the veins and margin and near margin with long, stout bristles as in $D$. speciophilus; the venation very similar to that species, but three apical forks, not quite alike in the two wings, in one as figured, in the other with the three forks about equal in length, all about as long as the third fork in wing figured; the stem of cubital fork is more than twice as long as in the Peruvian species. In the hind wing the venation is very similar to the other species.

Length-1.2 $\mathrm{mm}$.

From Brownsville, Texas.

\section{HEMEROBIID $2 \mathrm{E}$}

Boriomyia ultima sp. nov.

Face uniform polished dark brown; vertex pale, with a median brown dot; antennæ and palpi pale yellowish; pro- 
notum pale, a broad, median brown stripe; rest of notum pale, side of the metanotum marked with brown; pleura mostly brown; legs pale yellow; abdomen dull yellowish. Wings hyaline; fore wings with several large brown spots, many irregular smaller marks, more or less forming oblique transverse bands, a row over each gradate series, the larger spots near middle, another row before the first gradate series, with the large spots behind, and a large spot over the cross-vein between medius and cubitus; veins pale, with scattered brown dots; margin interruptedly pale and brown. Hind wings pale; veins pale, a few gradate veins dark. Fore wings not very broad, four radial sectors, the fourth forked once before the cross-vein, no cross-vein between the first and second sectors near base.

Expanse $15 \mathrm{~mm}$.

From Angora Peak, Tahoe, Calif. (Van Duzee.)

Synopsis of Species of Boriomyia of United States

1. No cross-vein between the last (third) radial sector and radius; one between first and second sectors near base; hind wings with tip and costal mark brownsubgenus-new Allotomyia, 2

A cross-vein between last radial sector (either third or fourth) and the radius; hind wings without large brown marks

2. Gradate series marked with dark brown .........speciosa Gradate series not dark, but broad brown area before first gradates and beyond the second gradates...fidelis

3. Face pale, with a few dark spots or dots................ 4

Face uniform shining brown ................................ 6

4. A large brown spot at base of antennæ truncate below; three radial sectors, the third usually forked but once before the cross-vein

No such spot, face with small dots; four radial sectors, or if three, the third forked twice before crossvein longipennis 
5. Fore wings with numerous brown bands across; pronotum with dark brown stripe each side....coloradensis Fore wing without such bands; pronotum not plainly marked pretiosa

6. A cross-vein between first and second radial sectors near base; wings heavily marked, usually four radial sectors or the third forked twice before the crossvein

No cross-vein between first and second radial sectors near base; usually three radial sectors and the third usually forked but once before cross-vein

7. Margin of fore wings heavily marked; pronotum with dark brown stripe each side longifrons

Margin of fore wings scarcely marked; pronotum not plainly marked transversa

8. Wing surface evenly fumose; veins not spotted; three radial sectors brunnea

Wings not evenly fumose; veins dotted or spotted with dark

9. Pronotum pale, unmarked; wings with only a few gradates dark schwarzi

Pronotum with lateral or median brown stripe; wings plainly spotted or banded with dark

10. Pronotum with broad brown median stripe. Wings with large spots tending to form bands; no lateral stripes; four radial sectors ultima

Pronotum with brown side stripes; and often median line; usually three radial sectors

11. Fore wings marked all over with dark spots in form of oblique, wavy bands, wings not especially long.

disjuncta

Fore wings with large dark spots mostly near outer and hind-margin, middle area scarcely marked; wings more elongate than usual posticata 


\title{
LIMNEPHILID $\not E$
}

\section{Limnephilus hageni sp. nov.}

\author{
Figs. 7, 8, 9.
}

Yellowish; thoracic notum brown, abdomen dull yellowish, to pale brown; legs pale, spines black, but several on front tibiæ yellow, hairs yellowish; wings yellowish, fore wing with posterior portion mostly yellowish brown, broken near middle by broad, oblique, pale area, a large brown spot near tip, and stigma mostly dark, the outer part of fourth and fifth apical cells and the first and second subapicals hyaline, base of apical cells and area before anastomosis also white hyaline, the brown contains but few pale spots.

Male genitalia related to $L$. sansoni, but the superior appendages smaller, the teeth on inner side differently arranged, the intermediate appendages black only at tip, somewhat curved, the lower appendages stouter and shorter. The female has two slender appendages very similar to those of $L$. sansoni. The species is quite a little smaller than L. sansoni.

Expanse $24 \mathrm{~mm}$.

- From Ft. Resolution, Great Slave Lake (Kennicott, 1862), Hagen had this by label of sublunatus, but the species Provancher sent Hagen as sublunatus is very different, the same as I described as L. macgillivrayi.

\section{Limnephilus roberti sp. nov.}

$$
\text { Figs. 10, 11, } 12 .
$$

Yellowish, head with yellow hair, basal joint of antennæ with some black hair in front; thorax mostly with yellowish hair, but some dark ones on pronotum; abdomen more brown; legs pale yellowish, spines black, in the male the front tarsi are very long. Maxillary palpi of male with second and third joints subequal, in female the fifth is longest, plainly longer than third, the fourth somewhat shorter than second.

Wings yellowish, with fine yellowish hair, venation partly pale, many veins especially near lower apex, margined with 
yellowish brown spots and patches, anal margin brown, with a few pale spots, a white mark on thyridium, just before the posterior anastomosis. Fore wings rather narrow, elongate, discal cell a little longer than pedicel.

Male genitalia have very short processes, the superior lobes are very pale, and not toothed, nor darkened within. In the female the superior plate has lateral spurs and a broad median lobe which is blackened beneath on the sides.

Expanse 20 to $22 \mathrm{~mm}$.

From Winnipeg Lake (Robt. Kennicott).

Limnephilus sackeni sp. nov.

Fig. 6.

Yellowish, abdomen more dull brown, spines on legs black, but a few inner ones near base of front tibiæ are yellowish; hair yellowish, some black on sides of face and under antennæ. Wings yellowish, fore wing with brown marks on plan of others of this section, the anal margin brown, streak through middle of wing, broken by the oblique hyaline spot beyond middle, region before and beyond anastomosis hyaline, surrounded with brown, which extends above to tip and below to the outer angle, stigma dark. Legs very slender, basal joint of tarsus of front legs about one-half of the tibia, but it is not equal to second plus third joint.

Male genitalia has the superior appendages rather long, reaching beyond lower appendages which are slender, the intermediate appendages are curved and much more slender than usual.

Expanse $31 \mathrm{~mm}$.

From Sault de Ste. Marie River, 8 Sept. (O. Sacken.)

Acronopsyche gen. nov.

Legs slender; no spines on under side of last joint of hind tarsi; spurs 1,3,3, tibia of front pair with a few spines. Basal joint of antennæ moderately elongate, beyond barely crenulate; a group of two or three macro- 
chætæ behind each ocellus. Pronotum very small. Wings very hairy, not granulate, discal cell of fore wings extremely long, fully four times as long as pedicel; radius bent at stigma, all apical cells fairly broad at base, first fork scarcely reaches back on discal cell; cubitus disjointed at posterior anastomosis, anal cell divided as usual. In hind wing the discal cell is also elongate, and the apical cells fairly broad near base. In the male the inner spur of the hind tibia is elongate, very attenuate, about twice as long as the outer spur.

Type A. pilosa.

In general appearance and structure related to Ecclisomyia, but the spur formula and short first fork separate it. It can be included in my table (Can. Ent. 1916, p. 121) by the following modifications.

29. At least one ocellar macrochæta present 30

No ocellar macrochætæ

30. Anal cell not divided; radius bent at the stigma, spurs $1,3,3$ Hylepsyche

Anal cell divided as usual $30 \mathrm{a}$

30a. Spurs 1, 2, 4, first fork long distance back on discal cell Ecclisomyia

Spurs 1, 3, 3, first fork scarcely back on discal cell Acronopsyche

31. Spurs 1, 3, 3, equal to No. 31 of table.

Spurs 1, 2, 2, membrane granulate-equal to No. 36 of table.

Spurs 1, 3, 4, equal to No. 33 of table.

Acronopsyche pilosa sp. nov.

Fig. 13.

Brown; face and rest of head with pale hair, black hair on sides of face and between antennæ, vertex with yellow hair. Basal joint of antennæ brown, with pale hair, 
beyond yellowish; in male the second and third joints of maxillary palpi subequal, in female the third 'joint is plainly longer than either the fourth or fifth; thorax with yellowish hair, abdomen pale on under side; legs pale, spines black, no spines on basal half of hind tibia, inner spur of male attenuate and elongate, about twice the outer spur. Wings very hairy, with long fringes, fore wings rather elongate, more or less irrorate with pale yellowish, and with spots on margin between tips of some of the veins, the hair between veins being largely pale, anastomosis especially behind broadly dark, stigma not especially marked, no hyaline dot on thyridium. Genital parts short.

Expanse $22 \mathrm{~mm}$.

Modoc Co., California, 20 July. (Lindsey.)

\section{SERICOSTOMATID $F$}

Neothremma gen. nov.

A Sericostomatid; the maxillary palpi of the male recurved, short, last joint with a long dense fringe on lower inner side; basal joint of antennæ elongate; ocelli present, but rather small, spurs $1,3,4$. Venation fairly regular in both sexes, in general similar to that of Silo; the discal cell long, forks 1 and 2 back on discal cell, forks 3 and 5 also present; in the hind wing forks 1,2 and 5 present, and the discal cell closed. Eyes not hairy.

Type N. alicia n. sp.

Includes apparently also Thremma deceptiva Bks.

Distinct from Thremma by shape of maxillary palpi of the male, and the presence of fork 1 in hind wings. From Silo to which it is possibly more related, it is separated by the ocelli, and but three spurs on middle tibiæ.

Neothremma alicia sp. nov.

Figs. 4, 5 .

Pale brownish; clothed with mostly pale yellowish hair; fringe on last joint of male maxillary palpus black; yellowish hair on basal joint of antennæ, and in the male 
a tuft of long curved hairs near the inner tip. Legs pale, spurs pale; male genitalia yellowish; a long slender median piece bent downward beyond middle, really of two appressed pieces as tip is seen from behind to be of two parts, a pair of slender nearly straight intermediate appendages, and a large ventral piece, hairy, its tip reaching the other parts. Wings with fine yellowish hair, stigma a little darker; first fork reaching back nearly to middle of discal cell, fork 2 only a little back on discal cell, fork 3 as far back as fork 2, tenth apical cell very short.

Expanse $13 \mathrm{~mm}$.

From Tolland, Colorado (G. S. Dodds).

Similar to $N$. deceptiva which was based on a female; it differs in having the first fork reaching further back on a shorter discal cell, and in that the tenth apical cell is much shorter.

\section{HYDROPSYCHID E}

\section{Dolophiliella gen. nov.}

Closely related to Dolophilus, having ocelli, palpi, vertex, spur formula, hairy hind tibia, and general shape of male appendages as in that genus. The venation is the same, except that fork 1 is lacking in both front and hind wings. In 1909 Ulmer described a new genus, Dolophiloides, for a form from Central Asia in which fork 1 was absent from the hind wings. This species has gone a step further in dropping that fork in the fore wings. It might be better to consider both this and Dolophiloides as subgenera of Dolophilus.

Type D. gabriella.

Dolophiliella gabriella sp. nov.

Fig. 14.

Yellowish; joints of antennæ marked with brown; palpi dark brown; vertex and pronotum with pale yellowish hair; legs yellowish, hind tibia of male with much long hair 
behind. Wings with rather brighter yellow hair, without markings, fringe mostly gray; hind wings with mostly gray hair; a hyaline white spot behind end of discal cell in the fore wing. The discal cell is fully as long as its pedicel, fork 2 reaches to cell, forks 3 and 4 pedicellate, fork 3 with a pedicel twice as long as that to fork 4 . In hind wings discal cell less than one-half the length of the third apical cell, fork 3 long pedicellate. The male genitalia has a broad, median nearly truncate projection from below; the lower appendages have the second joint nearly three times as long as the first, and enlarged at tip.

Expanse $12 \mathrm{~mm}$.

From the San Gabriel Mts., Calif., June. (Grinnell.)

Nyctiophylax marginalis sp. nov.

Fig. 15.

Brown, head with pale yellowish hair, palpi brown, antennæ pale yellowish, pronotum with pale hair in the middle and brown on the margins, legs very pale, front tibiæ on outer side dark. Fore wings brown, clothed with brown and yellowish or golden hair, paler than in $N$. vestitus, around the outer margin are about eight to ten pale spots, between them the margin is darker; sometimes some of the spots are faint; hind wings brownish, with fine yellow hair, the fringe gray. In shape the wings are hardly as broad at stigma as in $N$. vestitus, the venation about the same as in that species.

Expanse $13 \mathrm{~mm}$.

From Put-in-Bay, Ohio. (G. Townsend.)

Plectrocnemia pallescens sp. nov.

Fig. 3.

Pale yellowish throughout and clothed with pale yellowish hair; hair of fore wings very short, appressed, and almost golden; veins pale, sometimes tips of apical veins darker, with a dark spot on margin, pale dot between each pair, a 
hyaline white streak on the median vein at fork and on cross-vein just beyond and on the cross-vein from median before the second apical fork; fringe wholly pale. Venation normal, discal cell long, four or five times as long as broad, fork 1 more than one-half of its pedicel ( $\delta$ ) or one-third of pedicel ( $q$ ) ; fork 3 plainly pedicellate, fork 4 before cross-vein; in the hind wings fork 1 is very short, fork 3 present in the female, not in male.

Expanse 13 to $15 \mathrm{~mm}$.

From Put-in-Bay, Ohio, August (G. Townsend); also St. Anthony Park, Minn. (Lugger.)

Explanation of Plate 12.

Fig. 1. Deipnopsocus texanus, fore wing.

Fig. 2. Deipnopsocus texanus, hind wing, scales.

Fig. 3. Plectrocnemia pallescens, genitalia.

Fig. 4. Neothremma alicia, head and antenna.

Fig. 5. Neothremma alicia, genitalia.

Fig. 6. Limnephilus sackeni, genitalia, side.

Fig. 7. Limnephilus hageni, genitalia, side.

Fig. 8. Limnephilus hageni, female, above.

Fig. 9. Limnephilus hageni, male, above.

Fig. 10. Limnephilus roberti, male, above.

Fig. 11. Limnephilus roberti, female, above.

Fig. 12. Limnephilus roberti, genitalia, side.

Fig. 13. Acronopsyche pilosa, genitalia, side.

Fig. 14. Dolophiliella gabriella, genitalia, side.

Fig. 15. Nyctiophylax marginalis, genitalia, side. 


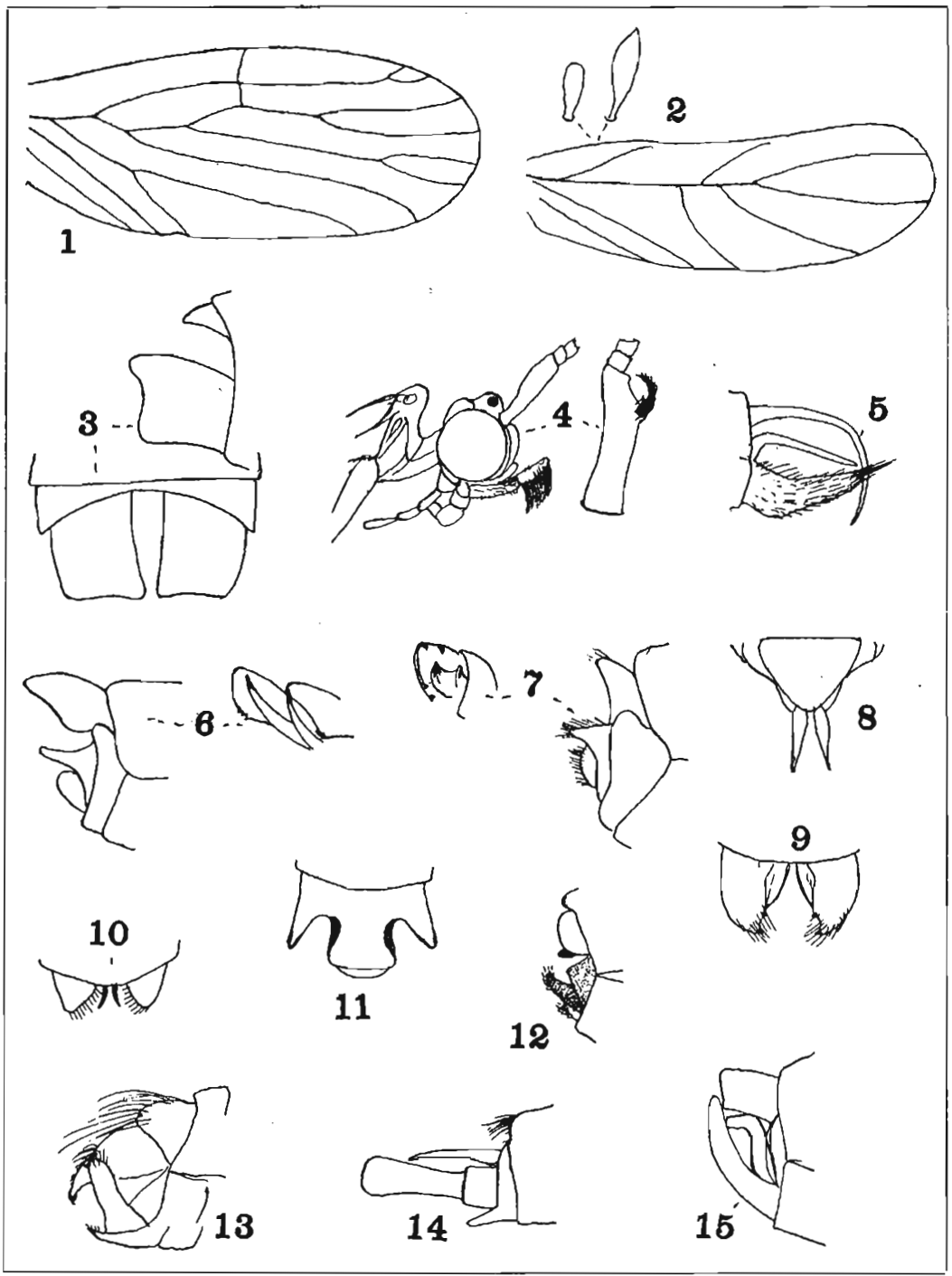

Plate 12.

Banks-Neuropteroid Insects. 

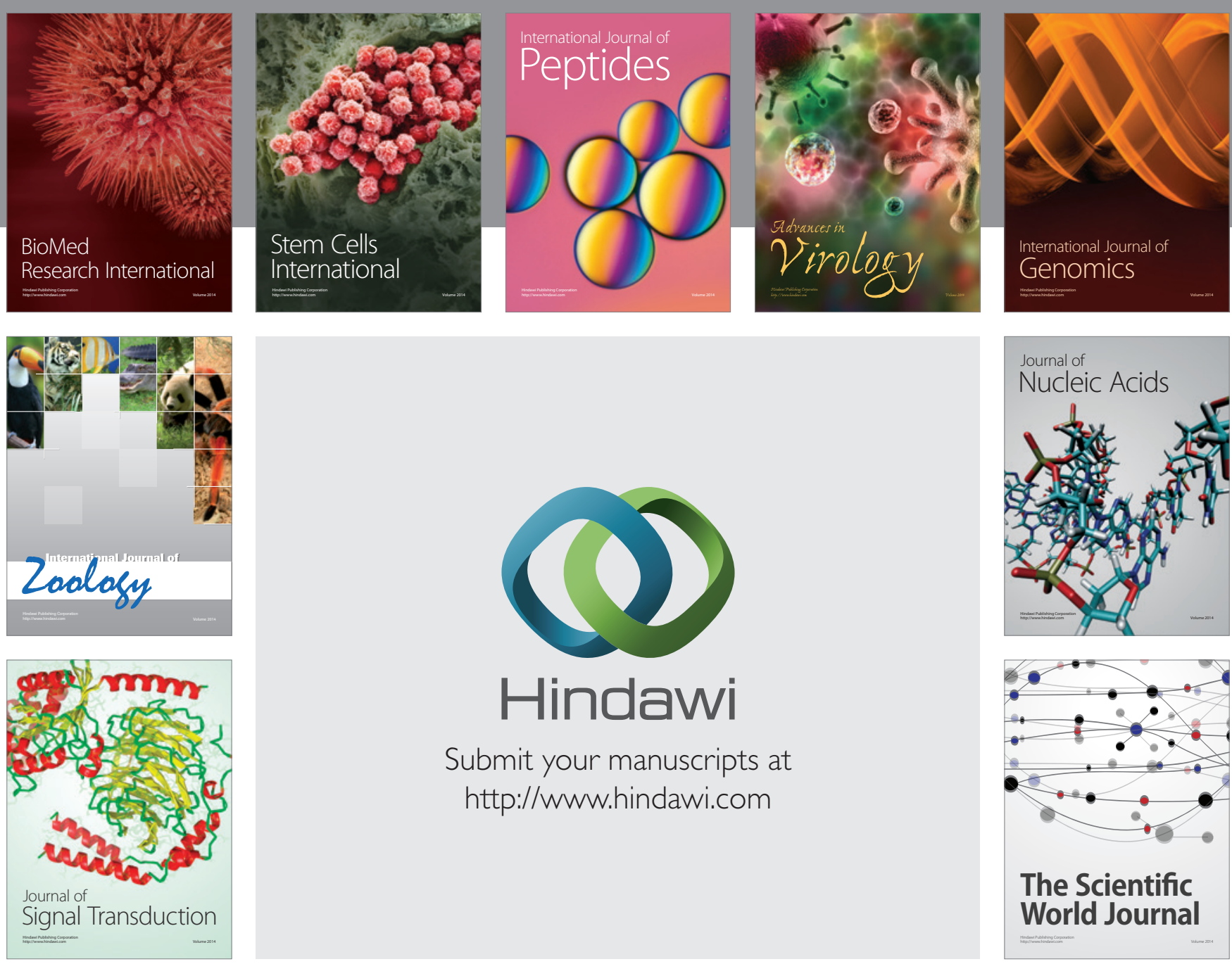

Submit your manuscripts at

http://www.hindawi.com
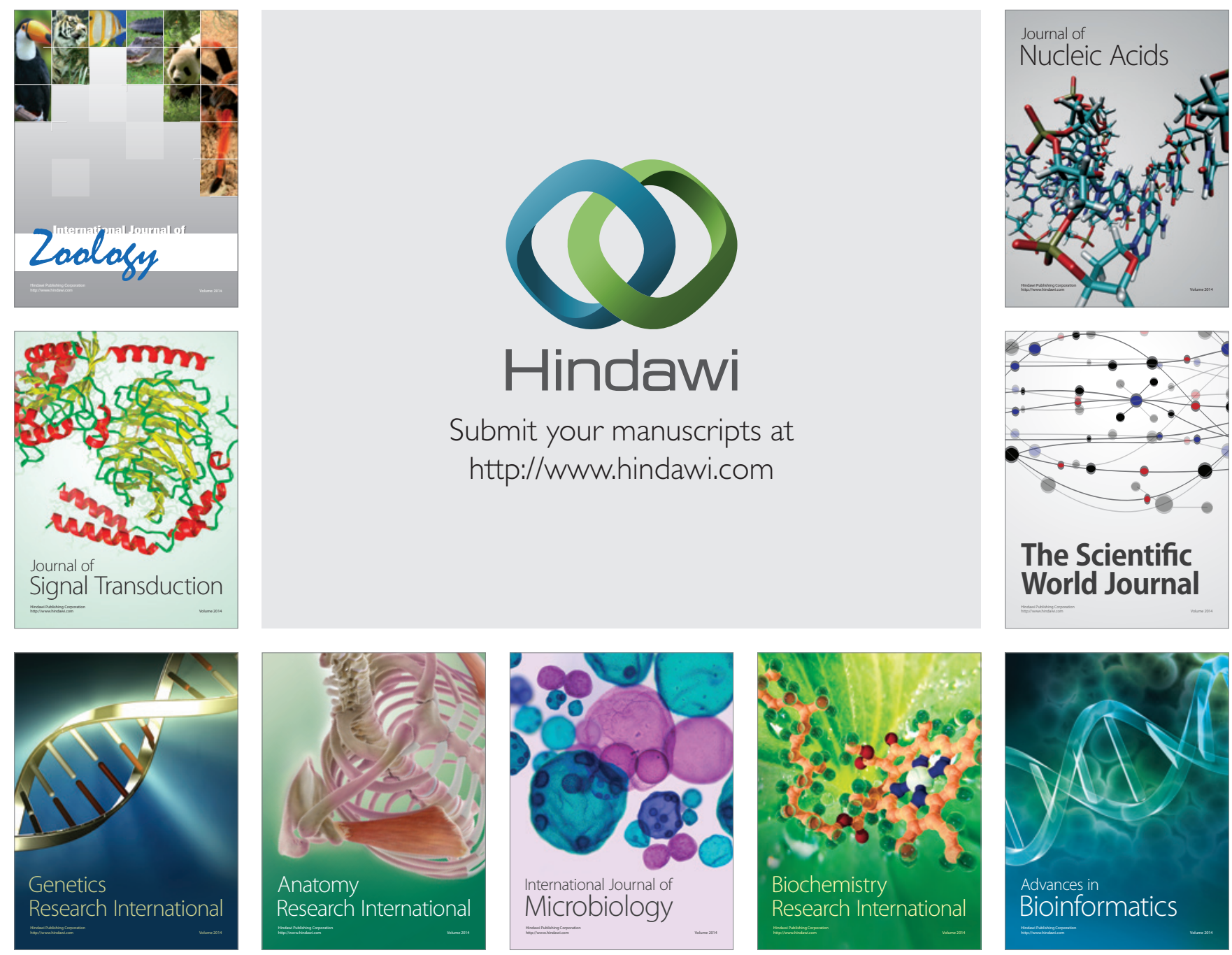

The Scientific World Journal
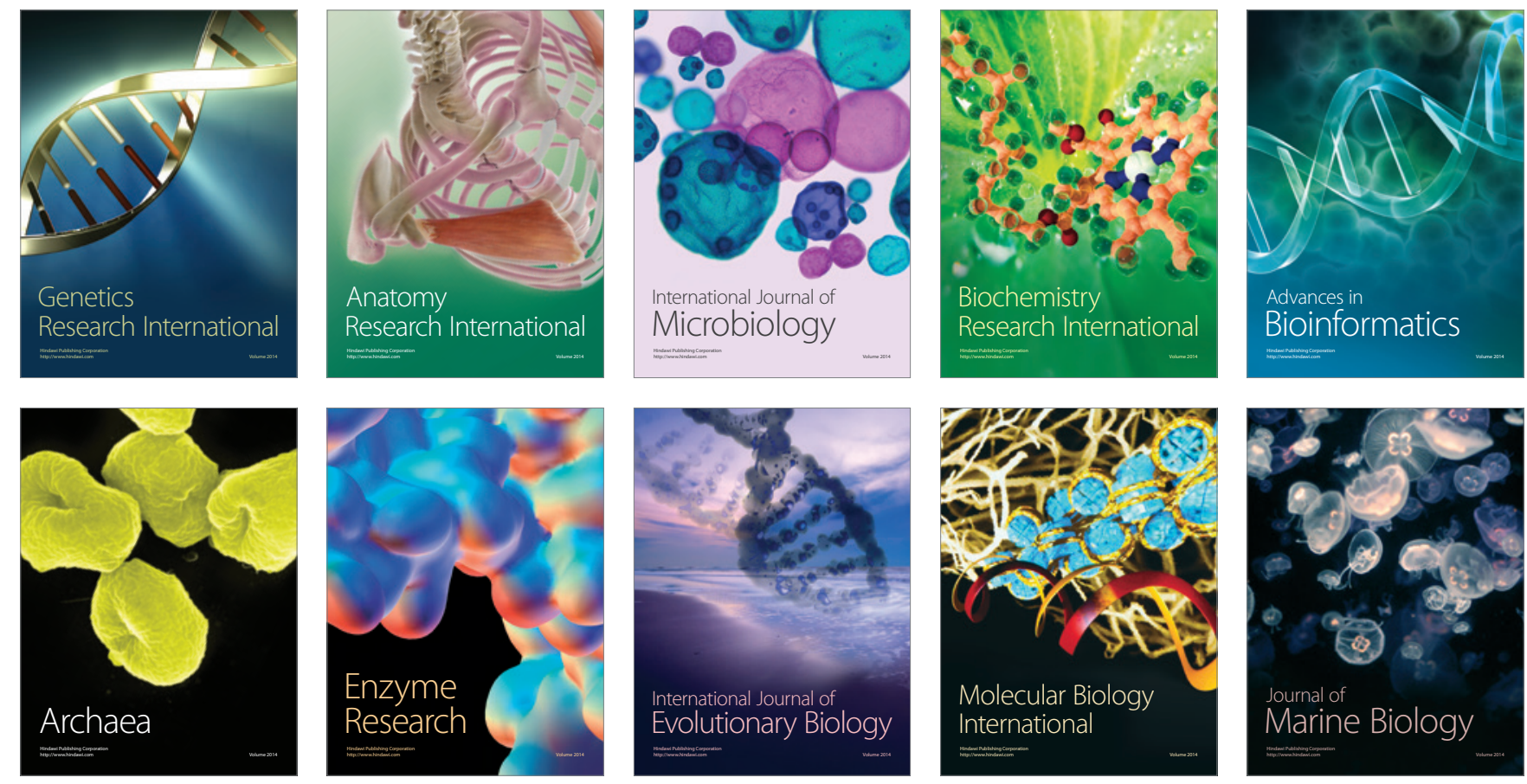